\title{
Modeling heat stress under different environmental conditions
}

\author{
M. J. Carabaño, ${ }^{* 1}$ B. Logar,† J. Bormann,‡ J. Minet,§ M.-L. Vanrobays,\# C. Díaz, ${ }^{*}$ B. Tychon,§ N. Gengler,\# \\ and H. Hammami\# \\ *Animal Breeding and Genetics Department, National Institute for Research and Technology in Agriculture (INIA), Ctra. de La Coruña kn7.5, \\ 28040 Madrid, Spain \\ †Animal Science Department, Agricultural Institute of Slovenia, SI-1000 Ljubljana, Slovenia \\ $\ddagger$ Administration of Agricultural Technical Services, L-1019 Luxembourg, Luxembourg \\ §Arlon Campus Environnement, University of Liège, B-6700 Arlon, Belgium \\ \#Animal Science Unit, Gembloux Agro-Bio Tech, University of Liège, B-5030 Gembloux, Belgium
}

\begin{abstract}
Renewed interest in heat stress effects on livestock productivity derives from climate change, which is expected to increase temperatures and the frequency of extreme weather events. This study aimed at evaluating the effect of temperature and humidity on milk production in highly selected dairy cattle populations across 3 European regions differing in climate and production systems to detect differences and similarities that can be used to optimize heat stress (HS) effect modeling. Milk, fat, and protein test day data from official milk recording for 1999 to 2010 in 4 Holstein populations located in the Walloon Region of Belgium (BEL), Luxembourg (LUX), Slovenia (SLO), and southern Spain (SPA) were merged with temperature and humidity data provided by the state meteorological agencies. After merging, the number of test day records/cows per trait ranged from $686,726 / 49,655$ in SLO to $1,982,047 / 136,746$ in BEL. Values for the daily average and maximum temperaturehumidity index $\left(\mathrm{THI}_{\mathrm{avg}}\right.$ and $\mathrm{THI}_{\max }$ ) ranges for $\mathrm{THI}_{\mathrm{avg}} /$ $\mathrm{THI}_{\max }$ were largest in SLO (22-74/28-84) and shortest in SPA (39-76/46-83). Change point techniques were used to determine comfort thresholds, which differed across traits and climatic regions. Milk yield showed an inverted U-shaped pattern of response across the THI scale with a HS threshold around $73 \mathrm{THI}_{\max }$ units. For fat and protein, thresholds were lower than for milk yield and were shifted around 6 THI units toward larger values in SPA compared with the other countries. Fat showed lower HS thresholds than protein traits in all countries. The traditional broken line model was compared with quadratic and cubic fits of the pattern of response in production to increasing heat loads. A cubic polynomial model allowing for individual variation in patterns of response and $\mathrm{THI}_{\mathrm{avg}}$ as heat load
\end{abstract}

Received August 4, 2015.

Accepted January 5, 2016.

${ }^{1}$ Corresponding author: mjc@inia.es measure showed the best statistical features. Higher/ lower producing animals showed less/more persistent production (quantity and quality) across the THI scale. The estimated correlations between comfort and $\mathrm{THI}_{\mathrm{avg}}$ values of 70 (which represents the upper end of the $\mathrm{THI}_{\text {avg }}$ scale in BEL-LUX) were lower for BEL-LUX (0.70-0.80) than for SPA (0.83-0.85). Overall, animals producing in the more temperate climates and semiextensive grazing systems of BEL and LUX showed HS at lower heat loads and more re-ranking across the THI scale than animals producing in the warmer climate and intensive indoor system of SPA.

Key words: Holstein cattle, heat stress model, climate change

\section{INTRODUCTION}

Heat stress (HS) effects on lactating cows have been widely studied because of the economic importance of the associated losses (St Pierre et al., 2003). However, optimization of the models that describe those effects has been paid much less attention. The model that has been traditionally used to describe the animal's productive response to increasing heat loads, the so-called broken line (BL) model, assumes that production remains constant within a thermoneutral region, where no response to increasing temperatures is observed and that, after the breaking point marking the start of HS, production decreases linearly (Misztal, 1999; Kadzere et al., 2002). However, this pattern may be too simplistic under the complex process that regulates milk production. Under the BL model, a value for the breaking point or comfort threshold of 72 for the most frequently temperature-humidity index (THI) used in cattle (NRC, 1971) is widely accepted (see, e.g., review by Zimbelman et al., 2009). However, patterns of animal response may differ across climatic conditions, production systems, or both. For example, in temperate regions, as opposed to warm areas, animals do not go through acclimation periods of gradual increase of 
heat loads during late spring and summer, but normally suffer the effects of high temperatures in sudden heat waves that do not last for long periods. In recent studies dealing with Holstein cattle in Central Europe, low THI thresholds for milk yield, at values of 60 in the German Holstein (Gorniak et al., 2014; Lambertz et al., 2014) and 62 in the Holstein population of Luxembourg (Hammami et al., 2013) have been found. In the Mediterranean region, Carabaño et al. (2014) found thresholds for milk, fat, and protein yields at 73,59 , and 62 , respectively, for Holstein cattle in southern Spain but using daily average temperatures instead of maximum values as in the previous studies. These results contrast with the results observed by Bernabucci et al. (2014) with Italian Holsteins who found THI thresholds at values of 73 to 76 for milk yield, 71 to 73 for fat and protein yields, and 65 to 71 for protein percentage. These different results point at differences in HS thresholds across climates, but they could also be associated with differences in the statistical models and methods used in each study. Moreover, Ravagnolo et al. (2000) found that for THI indices based on daily maximum temperature and minimum relative humidity, this combination of daily values showed a slightly superior goodness of fit than other combinations under the hot and humid conditions of Georgia (United States), but this superiority has not been tested under other environmental conditions.

Alternative functions to the BL model to describe the pattern of response in milk production to increasing heat loads can also be considered. Recently, several authors have used polynomial functions, which provide more flexible patterns than the BL model, to fit milk production response to increasing heat loads (Brügemann et al., 2011; Hammami et al., 2013; Carabaño et al., 2014). Little research has been done as to what polynomial degree should be used and whether the same type of function is optimal under different environmental conditions.

Apart from the average or population response to increases in heat load, estimation of individual deviations from the average response are the target for management and genetic selection of cows. The pattern of individual deviations is expected to be determined by differences in the HS threshold and the magnitude of the negative effect of HS among cows. Estimation of individual thresholds under BL models has been proven to be cumbersome (Sánchez et al., 2009) because of the complexity of the needed models. Again, polynomial functions have been used to describe individual deviations to avoid these drawbacks (Brügemann et al., 2011; Hammami et al., 2013; Carabaño et al., 2014).

The objective of this study was to explore average and individual patterns of response of milk production performance to HS under different climatic conditions and production systems, represented by 3 regions in Europe. Using a unified methodological framework to compare results across environmental conditions will allow identification of differences in heat stress effects due to differences in environmental conditions and not to the methods, as when comparing results from different studies. Different models varying from the traditional BL model to polynomial approximations and relying in different indices to measure heat load are used to predict response of milk production traits to increasing heat loads in each climate.

\section{MATERIALS AND METHODS}

\section{Productive and Weather Data}

Milk, fat, and protein test-day records came from official milk recording programs, for 1999 to 2010 inclusive, in 4 Holstein populations located in the Walloon Region of Belgium (BEL), Luxembourg (LUX), Slovenia (SLO) and in 2 regions with the hottest temperatures in southern Spain (SPA). Data were provided by the corresponding breed associations, Walloon Breeding Association (AWE), Convis Herdbuch Service Elevage et Génétique, Agricultural Institute of Slovenia and the Confederation of Associations of Spanish Friesian (CONAFE), respectively. The associations furnished 1,982,047, 994,927, 686,726, and $1,589,563$ test-day records collected from 136,746, $59,040,49,655$, and 105,223 cows in BEL, LUX, SLO, and SPA, respectively.

Those populations were chosen because they represent a comprehensive range of environments in terms of meteorology and production systems across Europe. According to the Köppen-Geiger climate classification (Peel et al., 2007), BEL and LUX have a temperate maritime climate, $\mathrm{Cfb}$. Slovenia, despite its small size, has a moderate continental climate with several subtypes in areas where Holstein cows are raised, which suits $\mathrm{Cfb}$, Cfa, and Dfb classes in the Köppen-Geiger system. For SPA, Andalusia has several sub-types of Mediterranean climate and Castile La Mancha, a continentalized Mediterranean climate, responding to Csa and Bsk classes of the Köppen-Geiger system. Production systems vary between semi-intensive grazing systems in BEL and LUX, mainly indoor semi-intensive to intensive production in SLO, and intensive indoor production in SPA.

Weather records were provided by the corresponding meteorological state agencies, Belgian Crop Growth Monitoring System consortium (B-CGMS), Administration des Services Techniques (ASTA), Slovenian Environment Agency (ARSO), and the Spanish Me- 
teorology Agency (AEMET). Records from 35, 14, 25, and 178 stations in BEL, LUX, SLO, and SPA, respectively, were used. Average/standard deviation/ maximum distance from the herds to the weather stations were $5.1 / 2.8 / 13.3,7.6 / 4.1 / 16.0,14.4 / 7.7 / 39.3$, and 13.3/7.9/30.0 km in BEL, LUX, SLO, and SPA, respectively. From daily dry bulb temperatures $\left(\mathbf{T}_{\mathrm{db}}\right.$, ${ }^{\circ} \mathrm{C}$ ) and daily percentage of relative humidity $(\mathbf{R H}, \%)$, a THI following NRC (1971) was obtained as

$$
\begin{aligned}
\mathrm{THI}=(1.8 \times & \left.\mathrm{T}_{\mathrm{db}}+32\right)-[(0.55-0.0055 \times \mathrm{RH}) \\
& \left.\times\left(1.8 \times \mathrm{T}_{\mathrm{db}}-26\right)\right] .
\end{aligned}
$$

This index combines both temperature and humidity and aims at providing a measure of the temperature load perceived by the animals. In our case, 2 alternative definitions of THI were analyzed, THI $_{\max }$ including daily maximum $\mathrm{T}_{\mathrm{db}}$ and minimum $\mathrm{RH}$, and $\mathrm{THI}_{\mathrm{avg}}$ obtained from daily average $\mathrm{T}_{\mathrm{db}}$ and $\mathrm{RH}$. Average for values of THI in the day of control and the 2 previous days were used in the subsequent analyses to take into account the lagged effect of weather variables on productive traits (West et al., 2003).

The number of test day records per trait used in the subsequent statistical analyses ranged from 686,726 in SLO to 1,982,047 in BEL. The number of cows involved ranged from 49,655 in SLO to 136,746 in BEL. The number of herds providing information ranged from 453 in SPA to 1,359 in BEL. Average herd size was largest (around twice the size in other countries) in SPA and smallest in SLO.

\section{Statistical Models}

Three sets of analyses were carried out. First, a mixed linear model (LSTHI) was fitted to obtain least squares estimates of THI effect on production traits for each population. These first analyses aimed at depicting patterns of HS effect on production and comfort thresholds across populations. The model used to estimate THI effects was as follows.

$$
\mathrm{y}_{i j k l n}=\mathrm{LADIM}_{i}+\mathrm{THI}_{j}+\mathrm{hys}_{k}+\mathrm{c}_{l}+\mathrm{e}_{i j k l n},
$$

where $\mathrm{y}_{i j k l n}$ is the test-day production record (milk, fat and protein yield, and fat and protein percentage), LADIM $_{i}$ is the effect of the $i$ th combination of lactation number-age at calving-days in milk (11 classes of 30 DIM in a given lactation-age at calving combination), $\mathrm{THI}_{j}$ is the $j$ th class of one unit of THI, hys ${ }_{k}$ is the effect of the $k$ th combination of herd, year, and season of calving (seasons defined as subsequent 2-mo periods starting from December-January), $c_{l}$ is the cow $l$ effect, and $\mathrm{e}_{i j k l n}$ is the residual term. Herd-year-season, cow, and residual effects were assumed to be independently and identically normally distributed with zero mean and variances equal to $\sigma_{\text {hys }}^{2}, \sigma_{\mathrm{c}}^{2}$, and $\sigma_{\mathrm{e}}^{2}$, respectively. The Remlf90 and Blupf90 software (Misztal et al., 2002) were used to obtain estimates of dispersion and position parameters, respectively.

In the second set of analyses, solutions for the THI effect in model [1] were used as the dependent variables to estimate change points $(\mathbf{C h P})$ in the relationship between production and heat load. These ChP would then determine the comfort threshold(s) in these populations. The Segmented package (Muggeo, 2003, 2008) of R (R Core Team, 2014) was used for this purpose. This package provides estimates of regression models (intercept and slope) with piecewise linear relationships having a fixed number of unknown ChP. It is an iterative procedure that needs starting values for the $\mathrm{ChP}$ parameters. Two runs of the estimation process were performed using starting values in the low or in the high range of the THI values for each country. The number of ChP, which needs to be provided before the model estimation, was set to values ranging from 1 to 4 for milk yield and from 1 to 3 for fat and protein yield and percentage.

In the third set of analyses, 5 alternative models fitting various continuous functions to describe the average effect of THI on production instead of THI classes were used. The last 2 models accounted for the fact that response to increasing THI may vary across individuals.

Model $\boldsymbol{B L}$. In this model, each studied trait was considered to change linearly with respect to the degrees of heat stress beyond the threshold point that had been previously estimated by the segmented line analyses:

$$
\mathrm{y}_{i j k l n \mathrm{~T}}=\mathrm{LADIM}_{i}+b\left(\mathrm{~T}_{\mathrm{o}}-\mathrm{THI}\right)+\text { hys }_{k}+\mathrm{c}_{l}+\mathrm{e}_{i j k \ln \mathrm{T}} .
$$

The covariable $\mathrm{T}_{\mathrm{o}}-\mathrm{THI}$ was set to zero for THI values below the specific population comfort threshold, $\mathrm{T}_{0}$.

Models LP2 and LP3. Both models consider each trait as a continuous function of THI using the Legendre polynomials of order 2 and 3 :

$$
\mathrm{y}_{i j k l n \mathrm{~T}}=\operatorname{LADIM}_{i}+\sum_{j=0}^{q} b_{j} x_{j}(\mathrm{THI}=\mathrm{T})+\operatorname{hys}_{k}+\mathrm{c}_{l}+\mathrm{e}_{i j k l n \mathrm{~T}}
$$

$$
\text { [3] and [4] }
$$

where $q$, the polynomial degree, varied between 2 (quadratic) for LP2 and 3 (cubic) for LP3, $b_{j}$ is the $j$ th 
polynomial regression coefficient and $x_{j}(\mathrm{THI}=\mathrm{T})$ is the $j$ th Legendre polynomial covariable $\left[x, 0.5\left(3 x^{2}-1\right)\right.$ and $0.5\left(5 x^{3}-3 x\right)$ for the linear, quadratic, and cubic terms] evaluated at the THI value $\mathrm{T}$, normalized to a $[-1,1]$ range of values.

Models LP2ani and LP3ani. Models [3] and [4] were modified to account for the individual variation of each animal's response along the THI scale.

$$
\begin{aligned}
\mathrm{y}_{i j k l n \mathrm{~T}}= & \operatorname{LADIM}_{i}+\sum_{j=0}^{3} b_{j} x_{j}(\mathrm{THI}=\mathrm{T}) \\
& +\operatorname{hys}_{j}+\sum_{r=0}^{q} \alpha_{r k} x_{r}(\mathrm{THI}=\mathrm{T})+\mathrm{e}_{i j k l n \mathrm{~T}},
\end{aligned}
$$

where, $\alpha_{r k}$ are random regression coefficients $(r=0$, $\ldots, 2$, or 3) fitted for each animal, $k$.

The covariance structure for the random regression coefficients was

$$
\operatorname{Var}(\boldsymbol{\alpha})=\mathbf{C}_{\mathbf{0}} \otimes \mathbf{I}
$$

where $\boldsymbol{\alpha}$ is a vector containing all regression coefficients for all animals in the data set, $\mathbf{C}_{0}$ is the (co)variance matrix among random regression coefficients, and $\mathbf{I}$ is the identity matrix. This implies that animals were considered to be independent variables.

A Bayesian approach via Gibbs sampling was used to obtain solutions for all the unknowns and statistics for Bayesian model assessment. Our own software written in the fortran90 language (López-Romero et al., 2003) was used. A total of 50,000 iterations were run with 10,000 discarded as burn-in. Post-Gibbs analyses were performed using the boa package (Smith, 2007) of $\mathrm{R}$ (R Core Team, 2014). Convergence of Gibbs chains was monitored by visual inspections of plots of samples and from the convergence information provided by the boa package.

The described models were compared by the goodness of fit, through the natural logarithm of the marginal density (LMD), and by the predictive ability of future data, using a checking function that measures the expected difference under the predictive distribution between an observation excluded from the total data to fit the model and its prediction (D). Both statistics are calculated by the program within the Gibbs sampling. Details of the calculation procedure for the model comparison statistics can be found in López-Romero et al. (2003). The best model is the one with the minimum value of $\mathrm{D}$ and the maximum value of LMD. Differences between LMD values for 2 models provide an estimate of the natural logarithm of the Bayes factor (see, e.g.,
Kass, 1993), which provides evidence of the superiority of one model over the other in the Bayesian framework.

\section{RESULTS AND DISCUSSION}

\section{Data Summary Statistics}

Descriptive statistics of production and meteorological variables for each country are shown in Table 1. Milk yield was highest for SPA, which, on the other hand, showed the lowest values for fat and protein percentage. The productive level of the 4 populations was within the range of productive levels for other Holstein populations (Bohmanova et al., 2007; Aguilar et al., 2009; Smith et al., 2013). For $\mathrm{THI}_{\max } / \mathrm{THI}_{\mathrm{avg}}$, SLO showed the widest range of values $(28-84 / 22-72)$ and SPA the shortest (46-83/39-76). It is relevant to note that SLO showed values for the hot end (90th percentile for productive traits; P90) of $\mathrm{THI}_{\max }$ closer to SPA and values for the hot region of $\mathrm{THI}_{\mathrm{avg}}$ closer to BEL and LUX. This would indicate that high summer temperatures in SLO were compensated, on average, by low minimum values, yielding average daily values closer to BEL and LUX than to SPA. When following the approach of Segnalini et al. (2013), approximately 10,20 , and $30 \%$ of the records in BEL/LUX, SLO, and SPA, respectively, have been taken, at least, under discomfort conditions $(72 \leq \mathrm{THI}<75)$, whereas 10 and $20 \%$ of records were measured under alert conditions $(75 \leq \mathrm{THI}<79)$ only in SLO and SPA, respectively.

\section{Raw and Adjusted Production Across THI}

Figure 1 shows raw average of yields recorded at successive $\mathrm{THI}_{\max }$ and $\mathrm{THI}_{\text {avg }}$ units together with solutions for THI effects obtained from the LSTHI model in [1]. Solutions for THI effects can be viewed as means of data adjusted by effects in model [1] for each THI unit. Raw and adjusted means showed different patterns of response, particularly in the case of milk yields. Adjustment of raw milk yield records by parity, herd, animal, and especially, by lactation stage, resulted in a flatter response to THI increase when compared with the trend for raw means. A positive linear trend was found for average DIM of records obtained at each THI unit across the THI scale, so that data recorded at the highest THI values belonged to cows that were at later lactation stages (on average, 180; 155 DIM in BEL and LUX, and 165 in SLO and SPA) than records obtained under the lower THI (on average, 140 and 145 DIM in BEL and LUX and 155 in SLO and SPA). The difference in DIM for records taken under cold versus hot conditions was significantly larger for BEL 
and LUX than for SLO and SPA, indicating a higher seasonality of calvings in those countries. Thus, average milk yield at high THI values were low not only due to effects of high heat loads, but also to the natural decline of the lactation curve in later stages. Adjusting by lactation stage should account for this. However, if a large confounding existed between DIM and THI, there might be an over-adjustment at high THI values with a corresponding underestimation of the effects of high heat loads. In these populations, a total confounding did not exist between DIM and THI because, at each THI value, cows were found to be in all stages of lactation. However, the distribution of DIM of records for each THI value was shifted toward higher values as THI increased. Differences between median values increased up to 70 and 20 DIM for BEL and LUX and SLO and SPA when lowest and highest THI values are compared, indicating that effects of heat stress might be somehow underestimated after the DIM adjustment. This underestimation might be more important in BEL and LUX. Both THI scales (maximum and average) showed quite similar patterns of adjusted response.

\section{Comfort Regions}

The patterns of response for milk yield and milk components were different (see Figure 1). Milk yield showed a decrease not only in the hot region but also for the colder temperatures. Two plateau areas, one below $55 / 60$ for $\mathrm{THI}_{\mathrm{avg}} / \mathrm{THI}_{\max }$ in BEL, LUX, and SLO and below $62 / 65$ for $\mathrm{THI}_{\mathrm{avg}} / \mathrm{THI}_{\max }$ in SPA, followed by an increase in production up to the second plateau, where milk production reached its maximum and would mark the comfort area were observed for this trait. Comfort regions comprised $\mathrm{THI}_{\mathrm{avg}} / \mathrm{THI}_{\max }$ values between $55 / 60$ and $69 / 75$ in BEL, $-/ 65$ and $-/ 73$ in LUX (no HS threshold was found for LUX under $\mathrm{THI}_{\mathrm{avg}}$ ), 56/61 and $72 / 83$ in SLO, and between $62 / 65$ and $73 / 74$ in SPA. For SLO, an additional ChP was found for milk at around a value of $27 / 35$ for $\mathrm{THI}_{\mathrm{avg}} / \mathrm{THI}_{\max }$, mark- ing a possible cold stress threshold. Slovenia was the only country with $\mathrm{THI}_{\text {avg }} / \mathrm{THI}_{\max }$ values under $27 / 35$. It is worth noting that confidence regions for estimated slopes and ChP were notably larger for milk yield than for fat and protein, indicating a less reliable estimation of $\mathrm{ChP}$ for this trait. A similar pattern of a comfort area marked by a low and a high temperature with decreasing productions outside this range has been observed in the study of Hill and Wall (2015) in Holstein cows in the UK, but only for animals kept outdoors. Gorniak et al. (2014), for Holstein cows in Germany also observed a decrease in milk yield at both extremes, cold and hot, of the THI range studied.

Fat and protein yields and percentages showed the BL model type of response with a flat response up to a HS threshold or a continuous decline with a steeper slope after the HS threshold.

Table 2 shows the estimated $\mathrm{ChP}$ associated with HS thresholds found for all traits with the segmented regression approach. For fat and protein yields, HS thresholds ranged for $\mathrm{THI}_{\mathrm{avg}} / \mathrm{THI}_{\max }$ from $47 / 53$ in BEL to 52/64 in SPA and from 52/62 in BEL to 63/69 in SPA, respectively. For fat and protein percentage, similar patterns were observed and thresholds were estimated at values for $\mathrm{THI}_{\text {avg }} / \mathrm{THI}_{\max }$ between $45 / 52$ in BEL to 52/59 in SPA for fat percentage and between $51 / 56$ in LUX to $65 / 60$ in SPA for protein percentage.

From these results, it seems that HS thresholds for milk components are lower than for total milk quantity and tended to be higher for protein than for fat yield. Across countries, SPA showed higher thresholds than the other countries for most cases. Acclimatization of cows to hot conditions might explain these differences because high temperatures are reached gradually and remain almost constant along the summer in SPA versus the short-term heat waves in BEL and LUX. Slovenia is an intermediate case. Short-term versus long-term acclimatization has been claimed to result in different responses to high heat loads (see, e.g., review by Kadzere et al., 2002), although it is still a not well

Table 1. Mean, standard deviation, and 10th and 90th percentiles (P10 and P90) for productive traits and daily average (avg) and maximum (max) temperature-humidity index (THI) in the 4 countries participating in this study

\begin{tabular}{|c|c|c|c|c|c|c|c|c|c|c|c|c|c|c|c|c|}
\hline Trait & \multicolumn{4}{|c|}{ Belgium } & \multicolumn{4}{|c|}{ Luxembourg } & \multicolumn{4}{|c|}{ Slovenia } & \multicolumn{4}{|c|}{ Spain } \\
\hline $\operatorname{Milk}(\mathrm{kg} / \mathrm{d})$ & 25.2 & 7.0 & 23.0 & 34.8 & 25.3 & 6.9 & 23.0 & 34.7 & 24.5 & 6.6 & 22.4 & 33.5 & 31.5 & 8.2 & 29.0 & 42.5 \\
\hline $\begin{array}{l}\text { Protein } \\
(\mathrm{kg} / \mathrm{d})\end{array}$ & 0.84 & 0.22 & 0.77 & 1.13 & 0.86 & 0.21 & 0.80 & 1.15 & 0.81 & 0.20 & 0.74 & 1.08 & 1.01 & 0.25 & 0.94 & 1.33 \\
\hline Fat $(\%)$ & 4.05 & 0.61 & 3.85 & 4.87 & 4.21 & 0.63 & 4.01 & 5.06 & 4.04 & 0.68 & 3.84 & 4.94 & 3.50 & 0.76 & 3.30 & 4.49 \\
\hline $\mathrm{THI}_{\max }$ & 56.1 & 11.3 & 40 & 71 & 57.8 & 11.1 & 42 & 72 & 59.7 & 14.1 & 39 & 78 & 66.6 & 8.9 & 55 & 78 \\
\hline
\end{tabular}


understood phenomenon (Bernabucci et al., 2010). The existence of heat mitigation facilities in many herds in the case of SPA might also be the cause for higher thresholds (see, e.g., Collier et al., 2006).

\section{Statistical Comparison of Response Functions}

Table 3 presents values for the 2 Bayesian statistical model comparison criteria for different models to describe patterns of response to increasing heat loads and for the 2 ways of describing the heat load, daily average, and maximum THI values. The factor with the largest effect on the predictive ability and goodness of fit of the models, in all countries and traits, was the individual animal response to increasing heat loads (models LP2ani and LP3ani). Thus, variability in animal response to HS is an important source of variation in milk production under both temperate and warm climates under the production systems in the studied populations.

Average daily values for THI rendered better results than maximum values in general, except in BEL for the predictive ability criteria, $\mathrm{D}$, for milk yield and protein $\%$. The fact that average values take into account both maximum and minimum temperatures may be expected to provide a better way of describing the effect of heat stress because low enough heat loads during the night might provide a relief from heat stress effects that compensate for the high heat loads during the day.

For the functions describing the pattern of response in milk production and its components to increasing heat loads (BL, LP2, and LP3 functions), polynomial functions were always superior to the BL approach, with the only exception of protein yield for the D criterion in SLO. The cubic polynomial (LP3) was best in most cases, but the quadratic polynomial (LP2) also provided good results in many cases, providing a way to decrease dimensionality of models, which may be relevant for the random regression models used to describe individual patterns of response.

\section{Individual Deviations from the Overall Population Response}

Given that individual variation in shapes of response to THI was a highly significant source of variation for milk production traits, this component was further investigated. Figure 2 shows estimated curves for cow deviation effects across $\mathrm{THI}_{\text {avg }}$ values for the top and bottom $1 \%$ cows (according to the production level at a comfort $\mathrm{THI}_{\text {avg }}$ value of 45 for BEL, LUX, and SLO and of 55 for SPA), for cubic polynomials (model LP3ani). Plots for $\mathrm{THI}_{\max }$ provided similar patterns and are not shown. The curves in Figure 2 represent individual deviations with respect to the average population pattern of response. Therefore, an animal showing an ascending pattern with THI, such as the animals in the bottom of graphics in Figure 2, is not expected to increase production as THI increases, but to show a less steep descending pattern than the average (once we add the individual deviation to the average pattern of response fitted for each trait and country), and could be considered as a more tolerant animal. Of all countries, SLO showed flatter curves, indicating a smaller effect of temperature and humidity on milk production for this country. The fact that maximum high temperatures during the day seem to be accompanied by lower temperatures during the night in this country together with a moderate production level might explain the smaller effect of summer temperatures in SLO.

For all countries, models, and traits, the least productive animals tended to show a lower decay in production (positive slopes for individual curves) at high THI values, with respect to the mean population response, and the opposite was observed for top animals, although less uniformly. Less productive animals are expected to cope better with high heat loads and that would explain a trend to show less effect of high THI values on their production level. On the other hand, highly productive animals would be expected to suffer the consequences of HS more intensely and show larger than average declines in production. Berman (2005) determined, by using a thermal balance model, a strong association between production level and the threshold temperature at which the decline of milk yield is significant. Yano et al. (2014) also found that "individual cows respond differently to heat and that cows producing relatively high quantities of milk tend to be particularly sensitive to heat" by using a very different statistical approach for Holstein cattle in Japan. No large differences in shapes were observed between the quadratic (LP2ani, not shown) and cubic (LP3ani) polynomials, except for BEL and LUX for which curves tended to flatten at the high THI extreme under model LP3ani.

To summarize the overall effect of increasing heat loads on variability in individual animal response, Figure 3 shows changes in the estimated ratio of variability among animals over the total estimated variability across $\mathrm{THI}_{\text {avg }}$ (again, results on the $\mathrm{THI}_{\max }$ scale were very similar to those for $\mathrm{THI}_{\text {avg }}$ and are not shown) values for quadratic and cubic individual response curves. In all countries and for both models, a decrease of variance in animal effects was observed, as might be expected from the converging trend of response curves for top and bottom animals as shown in Figure 
a)
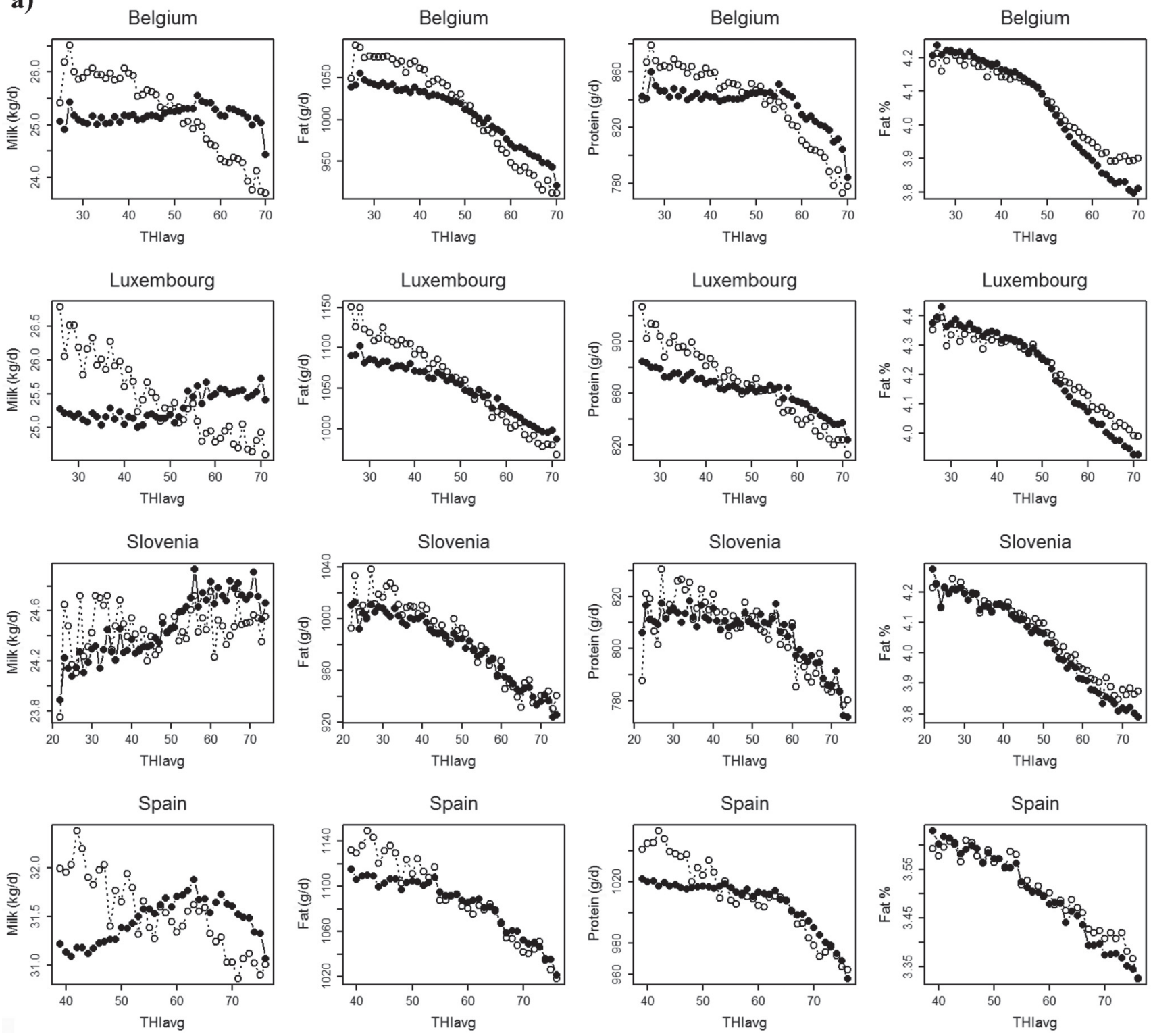
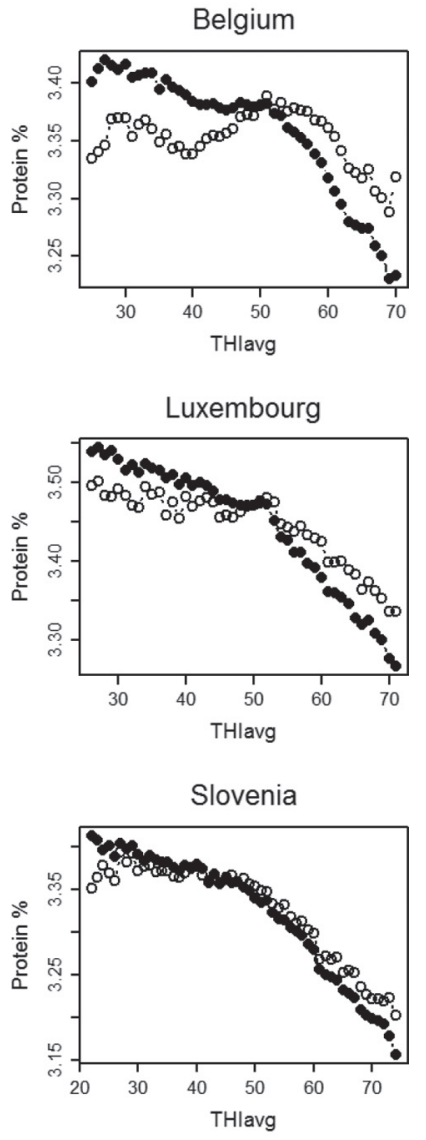
THIavg); (b) graphs for maximum THI (THImax). 

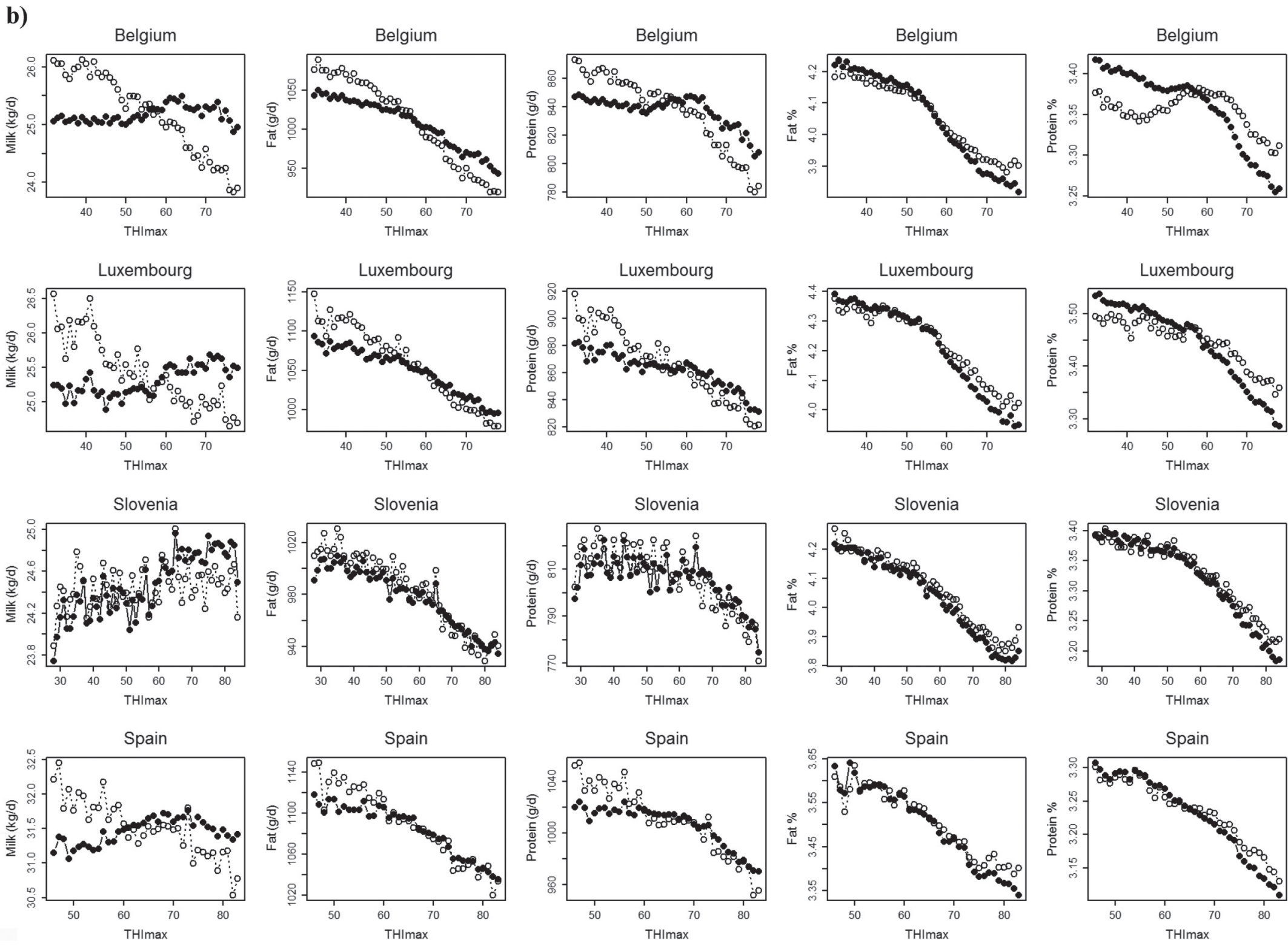

Figure 1 (Continued). Raw means of production traits $(\bigcirc)$ for each temperature-humidity index (THI) unit and least square solutions for THI effect $(\bullet)$. (a) Graphs for daily average THI (THIavg); (b) graphs for maximum THI (THImax). 
Table 2. Estimate (Estimt) and SD of change points for the response of productive traits to increases in daily average (avg) and maximum (max) temperature-humidity index (THI) in the 4 countries participating in this study

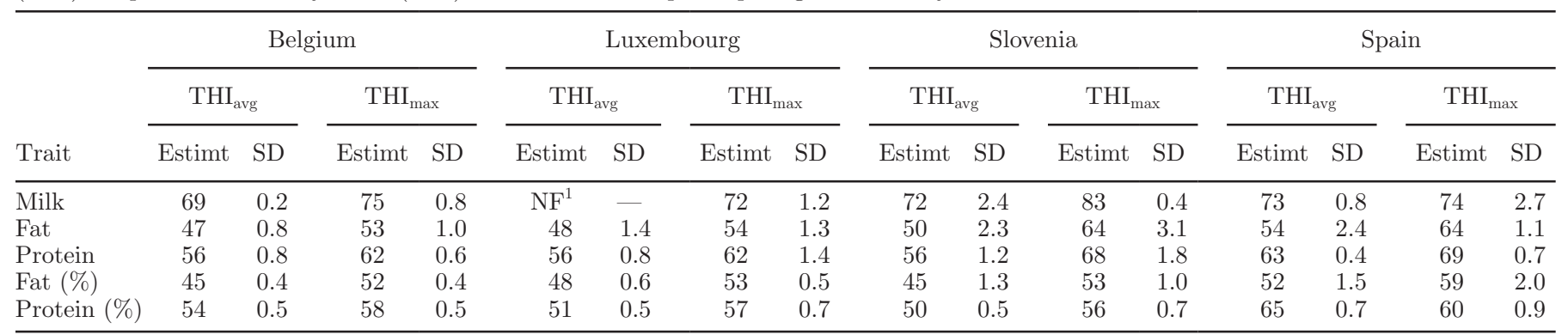

${ }^{1} \mathrm{NF}=$ not found.

2. The BEL and LUX showed a more drastic decrease in variance across the THI values, and SLO showed a flatter pattern of response, which is again an indication of a smaller effect of temperature on production in this country. A decrease in variability as temperature increases can be explained by the fact that a restrictive environment, such as high heat loads, may impair the expression of the full genetic potential of highly producing animals and cause a reduction in the observed variability of production. This result resembles the reduction in genetic variance observed under restrictive herd management conditions found in several studies about heterogeneity of variances in dairy cattle (Calus et al., 2002). Moreover, results from simulation studies on reaction norms of productive traits across continuously valued environments show that the ratio of animal variance to total variance decreases as the environment quality decreases when a negative correlation between intercept and slope of reaction exists (Calus et al., 2004). As mentioned later, a negative correlation between intercept and slope was found in our study and our results agree with the simulation studies of Calus et al. (2004).

Another interesting feature derived from analyzing individual curves of response is shown in Figure 4, where estimated correlations between animal effects under comfort $\left(\mathrm{THI}_{\mathrm{avg}}=45\right.$ in BEL, LUX, and SLO, and equal to 50 in SPA) or cold $\left(\mathrm{THII}_{\mathrm{avg}}=35\right.$ for BEL, LUX, and SLO, and equal to 40 for SPA) conditions and animal effects for all the range of THI values are presented for LP2ani and LP3ani models. Patterns for $\mathrm{THI}_{\mathrm{avg}}$ and $\mathrm{THI}_{\max }$ were very similar and only the first are shown. High correlations between animal effects at 2 THI values indicate that a similar ranking of the animals is expected at the 2 heat load values. In other words, no animal by environment interaction is expected, and vice versa. Both polynomial models (LP2ani and LP3ani) provided quite similar patterns of estimates, except for small discrepancies at the ex- tremes for BEL and LUX and for SPA for correlations with the cold THI.

Estimated correlations with comfort or cold THI values differed across traits and across countries. Correlations between animal effects at comfort or cold temperatures and animal effects at high heat loads were smaller for yields than for percentages and lower for fat compared with protein. Across countries, those correlations were larger for SLO compared with the other countries for all the range of THI values. Comparisons among the other 3 countries is not easy because the comfort region in SPA seems to be shifted 6 to $7 \mathrm{THI}_{\text {avg }}$ units higher (according to estimated comfort thresholds shown in Table 2). If we compare then the estimated correlations between comfort and $\mathrm{THI}_{\mathrm{avg}}$ values of 70 (which represents the upper end of the $\mathrm{THI}_{\text {avg }}$ scale in BEL-LUX), we find smaller correlations for BEL-LUX (between 0.70 and 0.80 for the yield traits) than for SPA (between 0.83 and 0.85 for the same traits). This would imply that more re-ranking of animals across heat loads (i.e., more animal by environment interaction) is expected for animals producing in the temperate than in the warm regions. Overall, the estimated correlations between comfort and HS were moderately high, which indicates that animals that are in the high range of production at comfort heat loads will remain to be in that range at high heat loads, although re-ranking is expected among animals in a similar production level, which agrees with the patterns of response shown in Figure 4 for the top and bottom productive animals. Correlations between cold and HS values dropped to values around 0.6 for BEL-LUX, 0.72 in SPA, and 0.75 for SLO. These lower correlations of animal effects at high THI values with the cold region indicate that reactions of animals to cold and heat situations are quite different. In other words, animals that are cold tolerant may not be hot tolerant and vice versa, and this raises the question of whether data obtained under cold conditions should 
Table 3. Differences between the model comparison criteria (D and LMD) ${ }^{1}$ for a given model ${ }^{2}$ (i) and the best model (best) under each criterion, using average (Av) or maximum $(\mathrm{Mx})$ daily values for the temperature-humidity index, for each trait in each country

\begin{tabular}{|c|c|c|c|c|c|c|c|c|c|c|c|c|c|c|c|c|c|c|c|c|}
\hline \multirow[b]{3}{*}{ Item } & \multicolumn{10}{|c|}{$\Delta \mathrm{D}=\mathrm{D}_{\mathrm{i}}-\mathrm{D}_{\text {best }}$} & \multicolumn{10}{|c|}{$\mathrm{LBF}=\mathrm{LMD}_{\text {best }}-\mathrm{LMD}_{\mathrm{i}}$} \\
\hline & \multicolumn{2}{|c|}{ Milk } & \multicolumn{2}{|c|}{ Fat } & \multicolumn{2}{|c|}{ Protein } & \multicolumn{2}{|c|}{ Fat $\%$} & \multicolumn{2}{|c|}{ Protein \% } & \multicolumn{2}{|c|}{ Milk } & \multicolumn{2}{|c|}{ Fat } & \multicolumn{2}{|c|}{ Protein } & \multicolumn{2}{|c|}{ Fat $\%$} & \multicolumn{2}{|c|}{ Protein $\%$} \\
\hline & $\mathrm{Av}$ & $\mathrm{Mx}$ & $\mathrm{Av}$ & $\mathrm{Mx}$ & $\mathrm{Av}$ & $\mathrm{Mx}$ & $\mathrm{Av}$ & $\mathrm{Mx}$ & $\mathrm{Av}$ & $\mathrm{Mx}$ & $\mathrm{Av}$ & $\mathrm{Mx}$ & $\mathrm{Av}$ & $\mathrm{Mx}$ & $\mathrm{Av}$ & $\mathrm{Mx}$ & $\mathrm{Av}$ & $\mathrm{Mx}$ & $\mathrm{Av}$ & $\mathrm{Mx}$ \\
\hline \multicolumn{21}{|l|}{ Belgium } \\
\hline $\mathrm{BL}$ & 57 & 57 & 808 & 890 & 766 & 785 & 25 & 26 & 9 & 9 & 76,155 & 76,201 & 58,958 & 61,912 & 83,934 & 85,395 & 45,567 & 46,904 & 60,805 & 61,756 \\
\hline LP2 & 56 & 56 & 793 & 877 & 787 & 802 & 23 & 32 & 7 & 11 & 75,666 & 75,392 & 58,114 & 61,182 & 85,037 & 85,971 & 46,134 & 47,239 & 60,343 & 60,867 \\
\hline LP3 & 56 & 55 & 786 & 876 & 765 & 785 & 28 & 26 & 10 & 9 & 75,345 & 74,962 & 58,055 & 61,098 & 83,872 & 84,994 & 45,013 & 45,693 & 59,139 & 60,201 \\
\hline LP2ani & 3 & 2 & 23 & 113 & 50 & 69 & 2 & 3 & 1 & 1 & 7,519 & 6,808 & 3,647 & 6,244 & 6,445 & 6,974 & 5,733 & 6,225 & 6,938 & 7,721 \\
\hline LP3ani & 1 & 0 & 0 & 85 & 0 & 15 & 0 & 0 & 0 & 1 & 1,813 & 0 & 0 & 2,320 & 94 & 0 & 505 & $\mathbf{0}$ & 0 & 969 \\
\hline \multicolumn{21}{|c|}{ Luxembourg } \\
\hline $\mathrm{BL}$ & 56 & 56 & 742 & 785 & 722 & 732 & 37 & 46 & 15 & 18 & 35,599 & 35,536 & 26,438 & 27,147 & 39,080 & 39,357 & 21,857 & 23,274 & 30,584 & 32,076 \\
\hline LP2 & 53 & 52 & 700 & 769 & 711 & 728 & 37 & 44 & 13 & 15 & 34,544 & 34,325 & 25,753 & 26,911 & 38,638 & 39,176 & 21,589 & 23,327 & 28,091 & 30,414 \\
\hline LP3 & 53 & 52 & 704 & 770 & 706 & 723 & 34 & 44 & 12 & 16 & 34,356 & 34,119 & 25,809 & 26,968 & 38,465 & 39,021 & 21,426 & 23,269 & 28,056 & 30,508 \\
\hline LP2ani & 2 & 3 & 27 & 116 & 40 & 79 & 0 & 8 & 0 & 3 & 2,995 & 3,129 & 2,361 & 3,627 & 3,548 & 4,528 & 2,217 & 4,271 & 2,730 & 5,832 \\
\hline LP3ani & 0 & 1 & 0 & 93 & 0 & 44 & 4 & 13 & 3 & 6 & 0 & 380 & 0 & 1,478 & 0 & 1,387 & 0 & 1,955 & 0 & 3,315 \\
\hline \multicolumn{21}{|l|}{ Slovenia } \\
\hline BL & 37 & 37 & 535 & 538 & 368 & 374 & 29 & 37 & 11 & 11 & 19,586 & 19,586 & 14,593 & 14,610 & 18,660 & 18,791 & 12,732 & 14,072 & 20,202 & 21,271 \\
\hline LP2 & 33 & 33 & 495 & 527 & 374 & 380 & 34 & 39 & 11 & 13 & 18,748 & 18,504 & 14,193 & 14,489 & 18,916 & 18,848 & 12,624 & 13,470 & 18,952 & 20,376 \\
\hline LP3 & 33 & 32 & 496 & 528 & 372 & 377 & 32 & 38 & 11 & 12 & 18,757 & 18,518 & 14,490 & 14,493 & 18,898 & 18,888 & 12,711 & 13,600 & 18,977 & 20,417 \\
\hline LP2ani & 0 & 3 & 5 & 82 & 7 & 45 & 7 & 16 & 2 & 5 & 1,455 & 2,250 & 939 & 1,975 & 1,577 & 2,548 & 858 & 2,545 & 1,003 & 3,571 \\
\hline LP3ani & 0 & 3 & 0 & 84 & 0 & 40 & 0 & 14 & 0 & 5 & 0 & 964 & 0 & 1,070 & 0 & 1,121 & 0 & 1,947 & 0 & 2,697 \\
\hline \multicolumn{21}{|l|}{ Spain } \\
\hline $\mathrm{BL}$ & 46 & 46 & 346 & 352 & 396 & 417 & 4 & 6 & 11 & 5 & 35,842 & 35,931 & 20,042 & 20,184 & 34,183 & 34,898 & 12,271 & 12,937 & 44,508 & 34,455 \\
\hline LP2 & 43 & 44 & 309 & 362 & 398 & 419 & 7 & 6 & 5 & 4 & 34,908 & 35,054 & 19,535 & 20,211 & 34,172 & 34,718 & 11,950 & 12,753 & 30,846 & 33,561 \\
\hline LP3 & 42 & 43 & 308 & 354 & 389 & 415 & 9 & 11 & 6 & 7 & 34,716 & 34,891 & 19,521 & 20,125 & 33,935 & 34,559 & 11,998 & 12,675 & 31,205 & 33,702 \\
\hline LP2ani & 0 & 6 & 0 & 83 & 7 & 75 & 0 & 4 & 0 & 2 & 1,711 & 4,752 & 1,891 & 3,700 & 2,040 & 5,489 & 351 & 1,742 & 0 & 5,815 \\
\hline LP3ani & 0 & 6 & 2 & 76 & 0 & 68 & 1 & 4 & 0 & 2 & 0 & 2,840 & 0 & 1,144 & 0 & 3,023 & 0 & 979 & 379 & 5,819 \\
\hline
\end{tabular}

글 ${ }^{1} \mathrm{D}=$ average of the expected values of the square of the difference between an observation excluded from the total data to fit the model and its prediction; LMD = natural loga黟. rithm of the marginal density of the data; $\mathrm{LBF}=$ natural logarithm of the Bayes factor.

œ ${ }^{2} \mathrm{BL}=$ broken line; LP2 $/ 3=$ quadratic/cubic Legendre polynomial $(\mathrm{LP})$ for overall response; LP2/3ani $=$ quadratic/cubic random LP for each animal. 

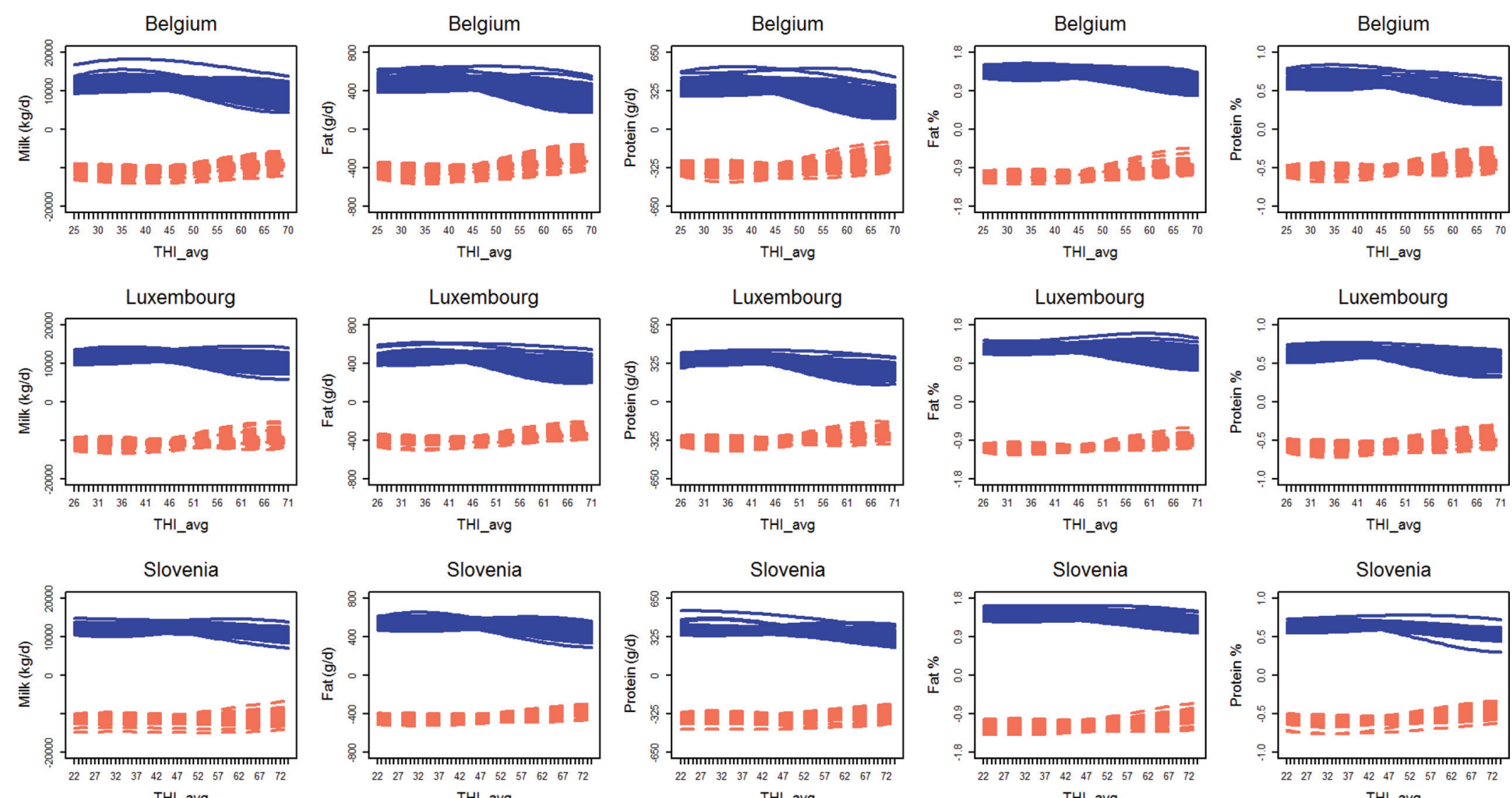

THI_avg
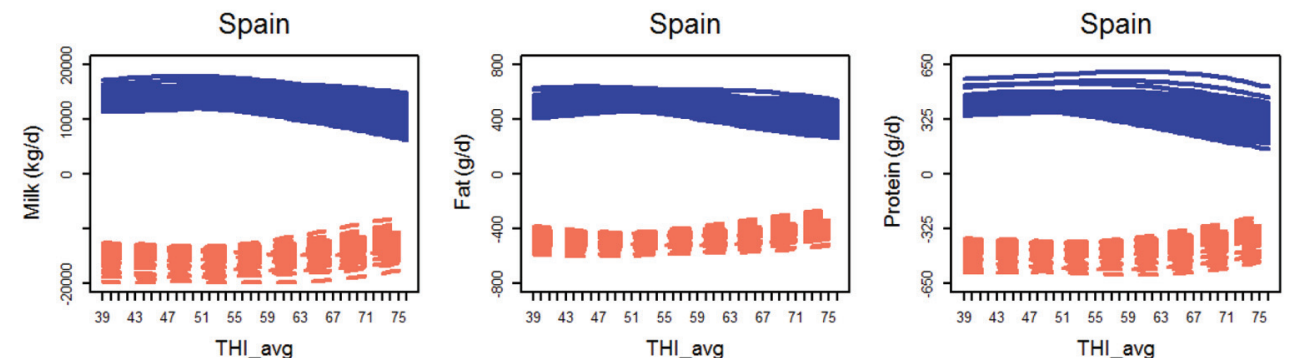

Figure 2. Estimated effects of top (solid lines) and bottom (dashed lines) $1 \%$ cows along temperature-humidity index (THI) values for combinations of traits and countries for a model fitting random cubic curves for cow effects (LP3ani). Color version available online. 

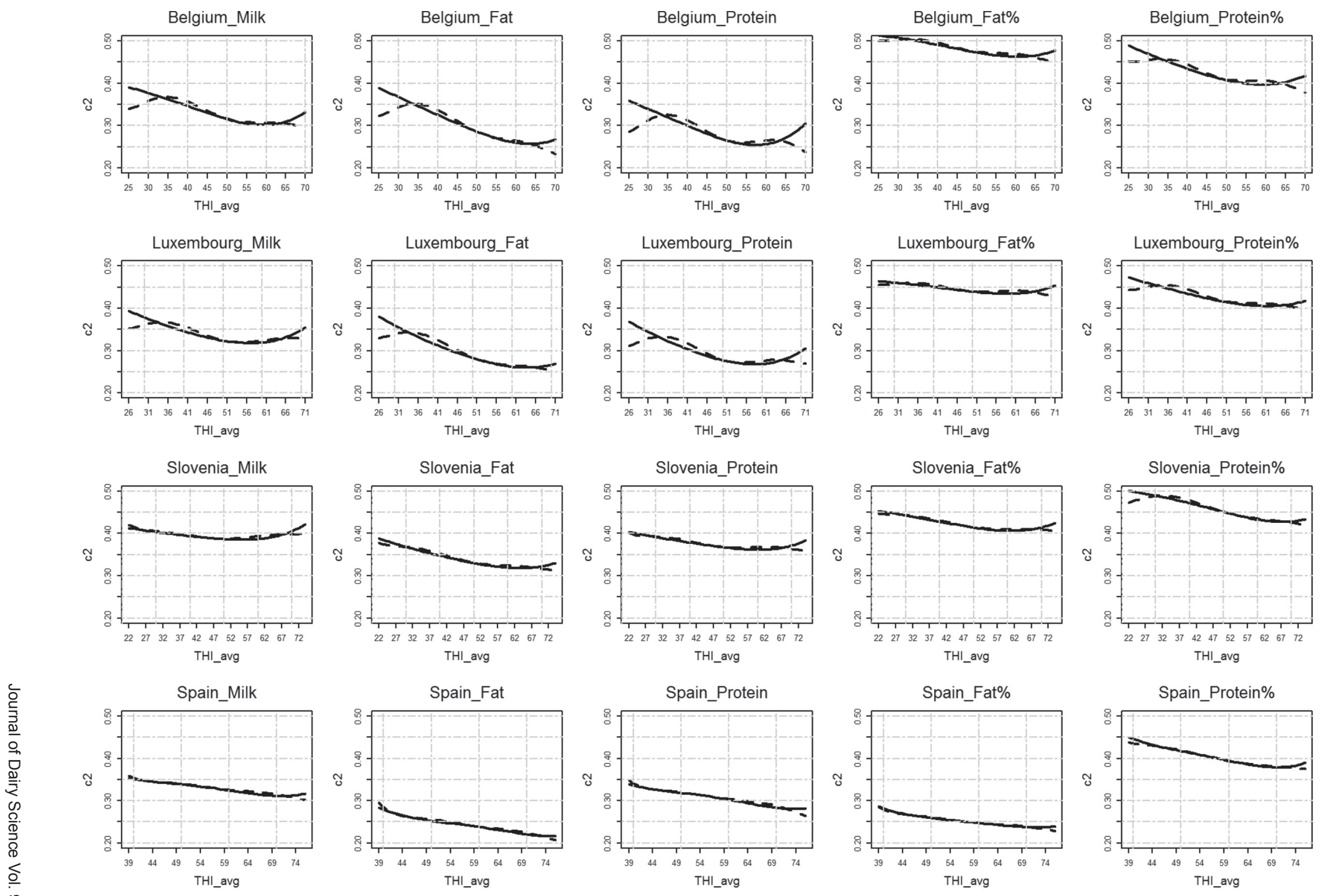

Figure 3. Posterior means of animal variance along temperature-humidity index (THI) values for models including quadratic (solid line) or cubic (dashed line) polynomials for animal effects. 

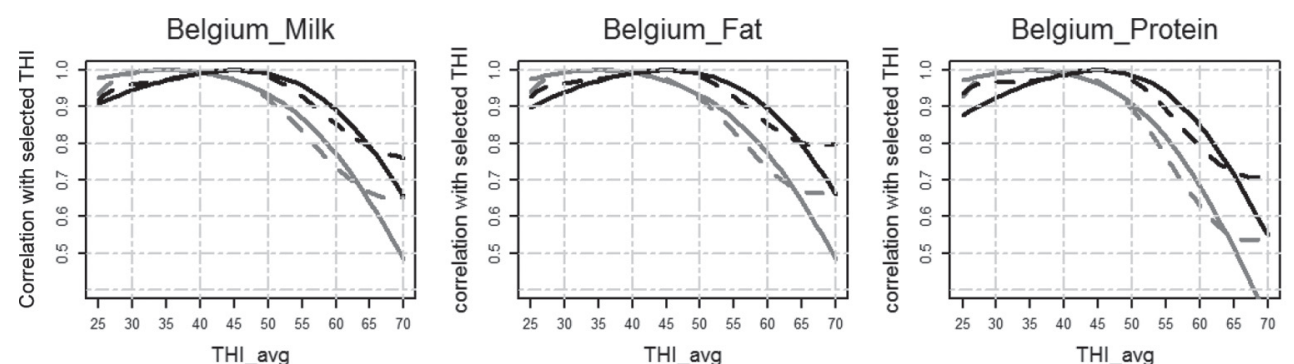

THI_avg
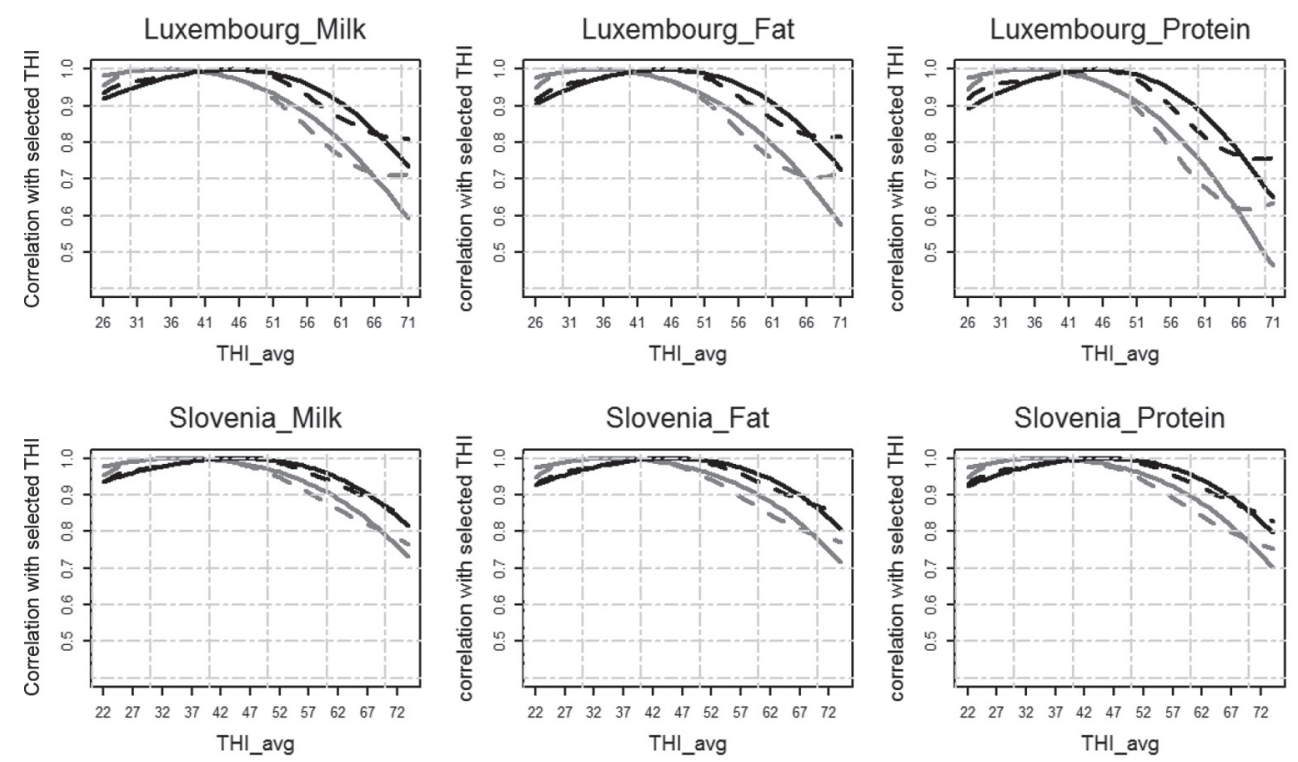

THI_avg
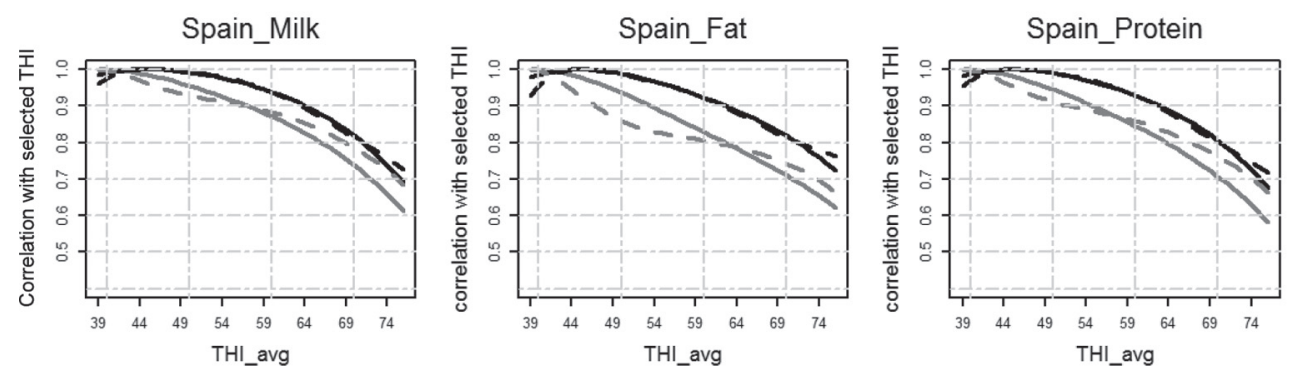
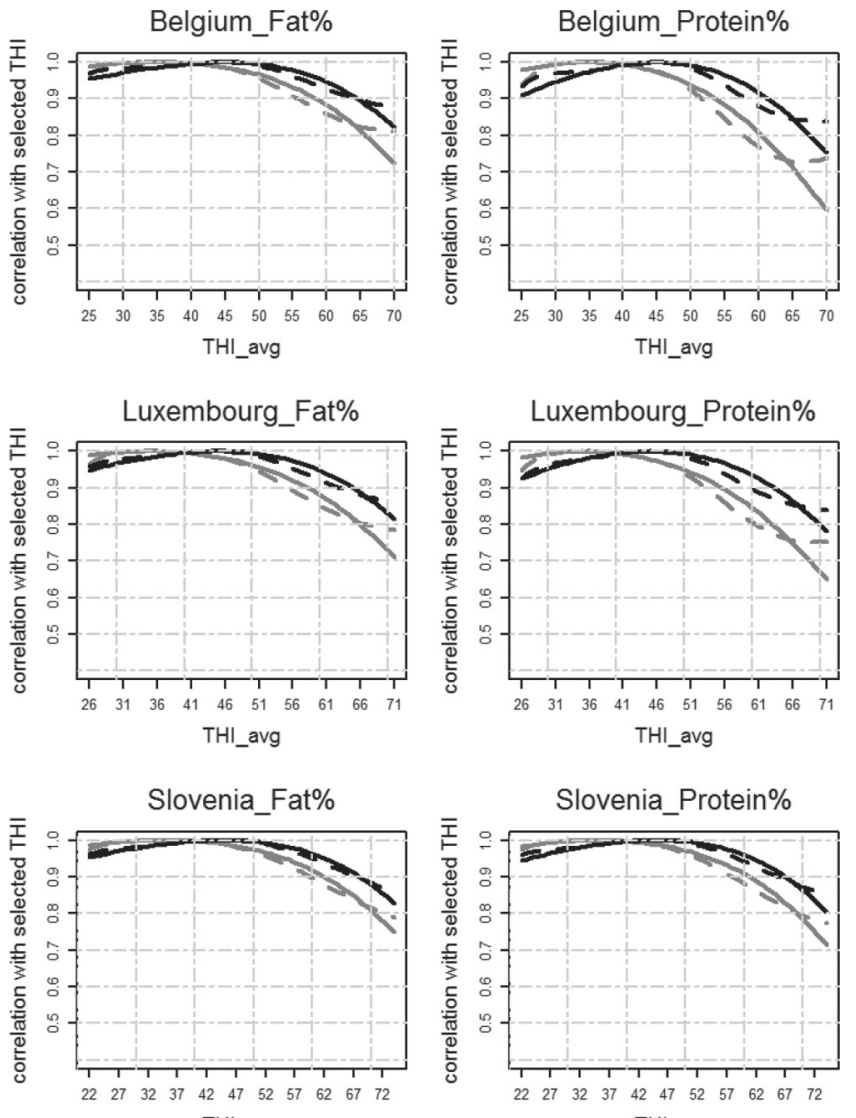

THI_avg
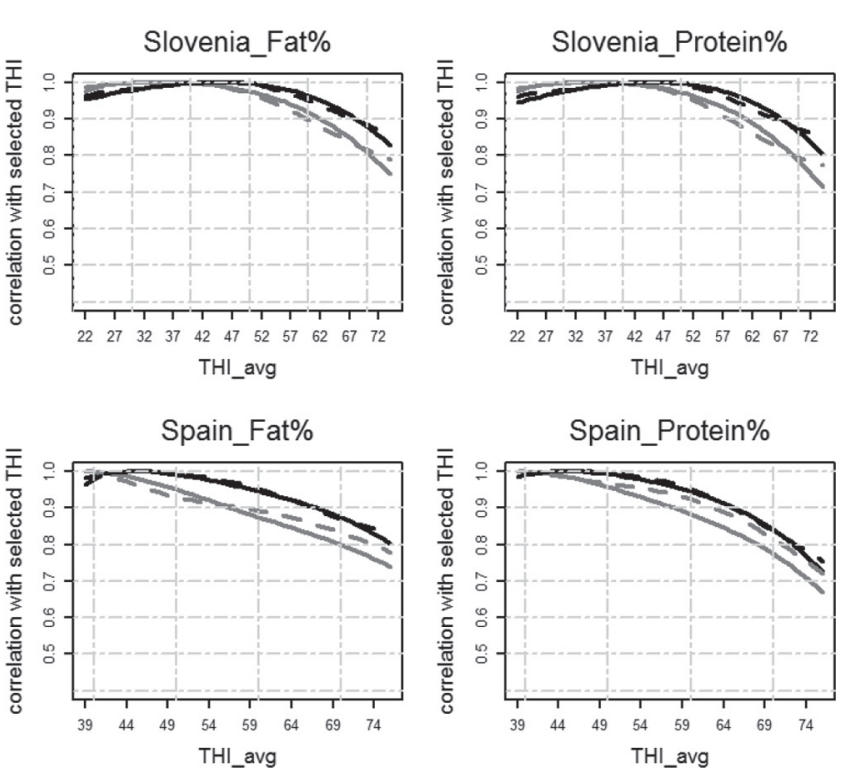

Figure 4. Posterior means of correlations between animal effects under a temperature and humidity index (THI) value of thermal comfort $\left[\right.$ daily average $\mathrm{THI}\left(\mathrm{THI}_{\text {avg }}\right)=45$, except for Spain $\mathrm{THI}_{\text {avg }}=50$, in black] or cold conditions $\left(\mathrm{THI}_{\mathrm{avg}}=35\right.$, except for Spain $\mathrm{THI}_{\text {avg }}=40$, in gray) and other THI values for models including quadratic ( $\mathrm{LP} 2$ ani, solid line) or cubic (LP3ani, dashed line) polynomials for herd year effects. 
be used to estimate reaction to HS using simplistic models such as the broken line.

\section{Productive Losses Associated with HS}

Finally, expected losses in production associated with HS obtained from the average population response and from individual estimated phenotypic response for the top $1 \%$ of animals and for the overall maximum individual response across countries and traits are presented in Table 4 for LP3ani models and for both $\mathrm{THI}_{\text {avg }}$ and $\mathrm{THI}_{\max }$. Given that $\mathrm{THI}_{\mathrm{avg}}$ and $\mathrm{THI}_{\max }$ have different scales, successive $\mathrm{THI}_{\max }$ values were fixed for all countries and corresponding $\mathrm{THI}_{\text {avg }}$ values were obtained from the estimated regressions of $\mathrm{THI}_{\mathrm{avg}}$ on $\mathrm{THI}_{\max }$ for each country. Differences between models LP2ani and LP3ani were small except for milk yield, for which the quadratic fit (results not shown), which only allows for one change in direction and does not seem to be adequate to describe the more complex reaction norm of milk yield to increasing THI values. Estimated losses from $\mathrm{THI}_{\text {avg }}$ and $\mathrm{THI}_{\max }$ did not differ largely but tended to be higher for $\mathrm{THI}_{\max }$ for milk yield in all countries and for $\mathrm{THI}_{\mathrm{avg}}$ for other traits, specially under the highest values of heat load.

On average, at the population level, milk volume losses due to high heat loads ranged from approximately $100 \mathrm{~g} / \mathrm{d}$ per THI unit for BEL and SPA to 10 to $19 \mathrm{~g} / \mathrm{d}$ per $\mathrm{THI}_{\text {avg }}$ or $\mathrm{THI}_{\max }$ unit for SLO at the extreme values for $\mathrm{THI}_{\text {avg }} / \mathrm{THI}_{\max }(73 / 82)$ and model LP3ani. However, when the $1 \%$ most productive animals were considered, those losses increased to 184 and $262 \mathrm{~g} / \mathrm{d}$ per THI unit for BEL and SPA, respectively, and 45.6 and $84.8 \mathrm{~g} / \mathrm{d}$ per THI unit for LUX and SLO, respectively. Across all populations, individual animals could show a decrease in milk volume up to $800 \mathrm{~g} / \mathrm{d}$ per THI unit due to high heat loads. For fat yield, losses at the extreme THI values $\left(73 / 82\right.$ for $\left.\mathrm{THI}_{\mathrm{avg}} / \mathrm{THI}_{\max }\right)$ for the population average were between 2.5 in SLO and $5.1 \mathrm{~g} / \mathrm{d}$ per THI unit for SLO and SPA, respectively, whereas for the top $1 \%$ cows, the range was from 5.3 to $10.5 \mathrm{~g} / \mathrm{d}$ per THI unit in the same countries. Overall, losses in fat yield reached values up to $26.5 \mathrm{~g} / \mathrm{d}$ per THI unit in some animals. For protein yield, population average loss ranged from 2.6 in SLO to $8.4 \mathrm{~g} / \mathrm{d}$ per THI unit in BEL, whereas for the top $1 \%$ animals losses ranged from 5.3 to $12.1 \mathrm{~g} / \mathrm{d}$ per THI unit for SLO and BEL and SPA, respectively. For individual animals, the estimated loss could be as high as $29 \mathrm{~g} / \mathrm{d}$ per THI unit. For fat percentage, at the extreme values for THI, rates of decay ranged from $-0.8 /-1.6 /-2.2 \times 10^{-2}$ in SPA to $-1.2 /-2.6 /-5.3 \times 10^{-2}$ in LUX for the population average/top 1\%/overall maximum. For protein percent- age, rates of decay ranged from $-0.9 /-1.2 /-1.6 \times$ $10^{-2}$ in SLO to $-2.1 /-2.6 /-5.5 \times 10^{-2}$ in BEL for the population average/top $1 \%$ /overall maximum.

Across countries, SLO showed the smallest losses associated with HS, except for fat and protein percentages, for which SPA showed similar or smaller losses than SLO. However, for the other 3 countries, losses were more similar for the population average but largest for SPA for the top 1\% animals for the 3 yield traits. Average population level of production was 25 $\mathrm{kg} / \mathrm{d}$ in BEL and LUX versus $31 \mathrm{~kg} / \mathrm{d}$ in SPA, whereas the top $1 \%$ animals in the phenotypic scale reached a production level in SPA of 51 versus $43 \mathrm{~kg} / \mathrm{d}$ in BEL and LUX. These results indicate that there might be a productive threshold beyond which animals would show more intense effects of high heat loads.

Estimated losses associated with HS in the literature vary largely depending on the metrics used to measure heat loads, measurement conditions (climate chambers vs. commercial conditions), measurement frequency (daily records vs. monthly test day information), parity, stage of lactation, and statistical modeling. Brügemann et al. (2012) compared the use of $\mathrm{THI}_{\max }$ versus $\mathrm{THI}_{\text {avg }}$ to estimate milk losses in German Holsteins in 3 different regions in Germany and obtained values ranging between $-0.08 /-0.16 \mathrm{~kg} / \mathrm{THI}$ for the crop region to $-0.26 /-0.47 \mathrm{~kg}$ for the maritime region of Germany for $\mathrm{THI}_{\max } / \mathrm{THI}_{\text {avg }}$. In the same population, Lambertz et al. (2014) observed large differences in estimated slopes of decay depending on lactation stage and housing system, ranging from 0 in early lactation and what they call "cold loose housing without grazing" to $-0.197,-0.009$, and $-0.006 \mathrm{~kg} / \mathrm{THI}$ in late lactation and "cold loose housing with grazing" for milk, fat, and protein yields, respectively. Finally, Freitas et al. (2006) found 5 times larger milk yield losses $(-1.12$ vs. -0.22 $\mathrm{kg} / \mathrm{THI}$ ) when estimating milk yield losses from daily records from animals measured in the same year and similar stage of lactation in an experimental station versus monthly test day records taken in a $10-y r$ period and concluded that "accounting for HS is much more complicated with test days than with daily records due to lack of accounting for HS in between the test days." For studies using commercial monthly test-day measures and THI as a measure of heat load, estimates range from maximum declines of $-0.6 \mathrm{~kg} / \mathrm{THI}$ at a $\mathrm{THI}_{\max }$ value of 76 for milk yield and $-0.04 \mathrm{~kg} / \mathrm{d}$ per THI and $-0.05 \mathrm{~kg} / \mathrm{d}$ per THI at THI equal to 72 for fat and protein yields, respectively, obtained for the Italian Holstein by Bernabucci et al. (2014) to values between 0 and $-0.18,-0.01$, and $-0.08 \mathrm{~kg} / \mathrm{d}$ per THI for milk, fat, and protein yields, respectively, for German Holsteins, estimated by Lambertz et al. (2014) at 
Table 4. Rate of decay for population average $(\mu)$, average rate of top $1 \%$ animals and overall maximum (OMax) of rates of decay at successive values of the temperature-humidity index (THI) estimated by cubic polynomial regressions to individual animals ${ }^{1}$

\begin{tabular}{|c|c|c|c|c|c|c|c|c|c|c|c|c|c|c|c|}
\hline \multicolumn{8}{|c|}{ Belgium } & \multicolumn{8}{|c|}{ Luxembourg } \\
\hline $\mathrm{THI}_{\text {avg }}$ & $\mu$ & Top $1 \%$ & OMax & $\mathrm{THI}_{\max }$ & $\mu$ & Top 1\% & OMax & $\mathrm{THI}_{\text {avg }}$ & $\mu$ & Top $1 \%$ & OMax & $\mathrm{THI}_{\max }$ & $\mu$ & Top $1 \%$ & OMax \\
\hline 45 & 19.3 & -10.3 & -423.0 & 50 & 19.9 & -32.3 & -391.9 & 44 & 16.7 & -2.2 & -344.6 & 50 & 18.5 & -18.2 & -309.1 \\
\hline 58 & -4.5 & -74.9 & -378.3 & 65 & 2.0 & -77.0 & -339.7 & 58 & 22.8 & -16.4 & -337.0 & 65 & 22.3 & -38.3 & -309.3 \\
\hline 66 & -47.6 & -128.6 & -238.9 & 75 & -48.4 & -94.6 & -211.8 & 67 & -0.5 & -31.1 & -132.4 & 75 & -7.3 & -44.1 & -150.2 \\
\hline 73 & -103.2 & -184.3 & -728.6 & 82 & -102.0 & -101.1 & -813.8 & 74 & -33.3 & -45.6 & -504.6 & 82 & -43.3 & -44.6 & -575.1 \\
\hline 58 & -3.8 & -7.6 & -18.9 & 65 & -3.0 & -7.1 & -16.3 & 58 & -3.0 & -5.9 & -18.4 & 65 & -2.8 & -6.5 & -17.2 \\
\hline 66 & -4.3 & -8.0 & -12.2 & 75 & -3.4 & -5.4 & -10.8 & 67 & -3.7 & -5.7 & -9.0 & 75 & -3.6 & -5.3 & -10.5 \\
\hline 73 & -4.6 & -7.5 & -26.5 & 82 & -3.5 & -2.7 & -27.5 & 74 & -4.3 & -4.6 & -22.2 & 82 & -4.1 & -3.2 & -24.2 \\
\hline \multicolumn{16}{|l|}{ Protein } \\
\hline 45 & 0.4 & -0.5 & -15.3 & 50 & 0.4 & -1.7 & -14.9 & 44 & -0.4 & -1.2 & -13.0 & 50 & -0.3 & -1.9 & -11.7 \\
\hline 58 & -1.6 & -4.1 & -14.3 & 65 & -1.1 & -4.1 & -13.3 & 58 & -1.2 & -3.0 & -12.9 & 65 & -1.1 & -3.8 & -12.6 \\
\hline 66 & -4.6 & -7.8 & -11.7 & 75 & -4.1 & -5.9 & -10.6 & 67 & -2.8 & -4.6 & -7.6 & 75 & -2.8 & -4.7 & -8.5 \\
\hline 73 & -0.003 & -0.017 & -0.047 & 782 & 0.002 & -0.006 & -0.051 & 74 & -0.012 & -0.026 & -0.053 & 82 & -0.009 & -0.021 & -0.057 \\
\hline \multicolumn{16}{|c|}{ Protein $\%$} \\
\hline 45 & -0.001 & -0.003 & -0.021 & 50 & -0.002 & -0.004 & -0.018 & 44 & -0.004 & -0.005 & -0.020 & 50 & -0.004 & -0.006 & -0.019 \\
\hline 58 & -0.007 & -0.010 & -0.022 & 265 & -0.006 & -0.009 & -0.018 & 58 & -0.009 & -0.011 & -0.025 & 65 & -0.008 & -0.012 & -0.023 \\
\hline 66 & -0.013 & -0.018 & -0.023 & 75 & -0.011 & -0.013 & -0.021 & 67 & -0.012 & -0.015 & -0.021 & 75 & -0.011 & -0.013 & -0.020 \\
\hline 73 & -0.021 & -0.026 & -0.055 & 82 & -0.015 & -0.016 & -0.050 & 74 & -0.015 & -0.018 & -0.044 & 82 & -0.012 & -0.014 & -0.041 \\
\hline
\end{tabular}

\begin{tabular}{|c|c|c|c|c|c|c|c|c|c|c|c|c|c|c|c|}
\hline $\mathrm{THI}_{\text {avg }}$ & \multicolumn{7}{|c|}{ Slovenia } & \multicolumn{8}{|c|}{ Spain } \\
\hline \multicolumn{16}{|l|}{ Milk } \\
\hline 56 & 19.3 & 25.5 & -290.6 & 65 & 17.9 & 9.9 & -229.7 & 58 & 25.7 & -2.7 & -396.8 & 65 & 24.1 & -27.1 & -410.2 \\
\hline 64 & 6.2 & -16.3 & -244.6 & 75 & 0.3 & -36.5 & -212.1 & 68 & -24.9 & -130.2 & -440.6 & 75 & -21.9 & -141.2 & -398.9 \\
\hline 70 & -9.3 & -63.3 & -206.7 & 82 & -19.5 & -84.8 & -222.1 & 75 & -86.1 & -262.2 & -416.0 & 82 & -78.5 & -249.6 & -386.0 \\
\hline 64 & -2.4 & -4.4 & -11.6 & 75 & -2.3 & -4.6 & -9.3 & 68 & -3.7 & -7.8 & -13.6 & 75 & -3.4 & -7.9 & -13.2 \\
\hline 70 & -2.5 & -5.3 & -8.9 & 82 & -2.7 & -5.4 & -8.9 & 75 & -5.1 & -10.5 & -15.8 & 82 & -3.7 & -8.3 & -16.3 \\
\hline \multicolumn{16}{|l|}{ Protein } \\
\hline 43 & 0.0 & 0.6 & -8.2 & 50 & 0.1 & 0.1 & -6.8 & 43 & -0.6 & 0.4 & -10.2 & 50 & 0.1 & 1.7 & -14.7 \\
\hline 56 & -0.8 & -0.9 & -9.6 & 65 & -0.6 & -1.4 & -8.6 & 58 & -0.6 & -1.8 & -13.6 & 65 & -0.9 & -3.2 & -14.0 \\
\hline 64 & -1.6 & -2.9 & -8.9 & 75 & -1.6 & -3.4 & -7.7 & 68 & -3.0 & -6.9 & -14.7 & 75 & -3.0 & -7.4 & -13.6 \\
\hline 70 & -0.009 & -0.015 & -0.027 & 82 & -0.008 & -0.013 & -0.025 & 75 & -0.008 & -0.016 & -0.022 & 82 & -0.004 & -0.012 & -0.019 \\
\hline \multicolumn{16}{|c|}{ Protein $\%$} \\
\hline 43 & -0.003 & -0.004 & -0.015 & 50 & -0.003 & -0.004 & -0.012 & 43 & -0.004 & -0.003 & -0.010 & 50 & -0.001 & 0.000 & -0.008 \\
\hline 56 & -0.006 & -0.008 & -0.020 & 65 & -0.005 & -0.008 & -0.017 & 58 & -0.005 & -0.007 & -0.019 & 65 & -0.006 & -0.009 & -0.021 \\
\hline 64 & -0.008 & -0.010 & -0.019 & 75 & -0.007 & -0.010 & -0.016 & 68 & -0.008 & -0.012 & -0.022 & 75 & -0.008 & -0.012 & -0.022 \\
\hline 70 & -0.009 & -0.012 & -0.016 & 82 & -0.008 & -0.011 & -0.014 & 75 & -0.011 & -0.016 & -0.023 & 82 & -0.009 & -0.014 & -0.019 \\
\hline
\end{tabular}

${ }^{1} \mathrm{THI}_{\text {avg }}=$ daily average value for THI. $\mathrm{THI}_{\max }=$ maximum daily value for THI .

a $\mathrm{THI}_{\text {avg }}$ of 60 . Our estimates lie in the lower side of the estimates for the German population, which might have been expected for the BEL and LUX data sets, but less so for the SPA data. As mentioned before, the acclimatization of cows together with the intensive indoor production system with heat mitigation facilities in the Spanish conditions versus the outdoor grazing conditions in the BEL-LUX populations may explain 
the smaller than expected differences observed across the studied countries.

\section{CONCLUSIONS}

The results found in this study indicate that comfort regions that allow maximum levels of productive traits are different across the climatic and production conditions of the studied populations and across traits. The upper limit of the comfort region for production traits was around 6 to 7 units of $\mathrm{THI}_{\text {avg }}$ higher in the warm Mediterranean regions of SPA than in the more temperate climate of BEL-LUX. The SLO showed a mixed situation, with thresholds similar to SPA when daily maximum heat loads were considered and closer to BEL-LUX when using daily average values. Across traits, fat production (both yield and percentage) showed lower HS thresholds than protein production. Polynomial models, which provide a more flexible function than the BL model, showed better statistical features in all climatic conditions and traits. The average daily value of THI as a heat load measure improved the statistical quality of models compared with the maximum daily value. Substantial variability in individual response to HS was observed in all countries. Animals with higher production level were more susceptible to HS effects and animals with lower levels of production were more tolerant than average animals, underlying the fact that lower level of production is a component of heat tolerance. A significant animal by environment interaction was found between cold and hot conditions, indicating that animals tolerant to HS are not expected to be also tolerant to cold temperatures. Overall, significant productive losses were found in both temperate and warm climates in Europe. Losses were similar in both types of climates but at higher heat loads in the warm region under an intensive production system.

\section{ACKNOWLEDGMENTS}

This study was the result of collaboration between several actors. The first author acknowledges the financial support of the project INIA-FEDER RTA201100108 (Ministerio de Economía y Competitividad, Madrid, Spain). The last author, as a former postdoctoral fellow, acknowledges the support of the National Fund for Scientific Research (Brussels, Belgium) for his fellowship. The authors thank the Walloon Breeding Association (Ciney, Belgium), Convis Herdbuch service Elevage et Génétique (Luxembourg, Luxembourg), Agricultural Institute of Slovenia (Ljubljana, Slovenia), and the Confederation of Associations of Spanish Friesian (Madrid, Spain) for providing test-day records.
They also thank Belgian Crop Growth Monitoring System consortium (Brussels, Belgium), Administration des Services Techniques (Luxembourg, Luxembourg), Slovenian Environment Agency (Ljubljana, Slovenia), and the Spanish Meteorology Agency (Madrid, Spain) for providing access to meteorological data. The authors are grateful to University of Liege (SEGI facility, Liege, Belgium) for the use of its NIC3 supercomputer. This work was conducted in the context of MACSUR (Modelling European Agriculture with Climate Change for Food Security), a project launched by the Joint Research Programming Initiative on Agriculture, Food Security and Climate Change (FACCE-JPI; coordinated by INRA, Paris, France).

\section{REFERENCES}

Aguilar, I., I. Misztal, and S. Tsuruta. 2009. Genetic components of heat stress for dairy cattle with multiple lactations. J. Dairy Sci. 92:5702-5711.

Berman, A. 2005. Estimates of heat stress relief needs for Holstein dairy cows. J. Anim. Sci. 83:1377-1384.

Bernabucci, U., S. Biffani, L. Buggiotti, A. Vitali, N. Lacetera, and A. Nardone. 2014. The effects of heat stress in Italian Holstein dairy cattle. J. Dairy Sci. 97:471-486.

Bernabucci, U., N. Lacetera, L. H. Baumgard, R. P. Rhoads, B. Ronchi, and A. Nardone. 2010. Metabolic and hormonal acclimation to heat stress in domesticated ruminants. Animal 4:1167-1183.

Bohmanova, J., I. Misztal, and J. B. Cole. 2007. Temperature-humidity indices as indicators of milk production losses due to heat stress. J. Dairy Sci. 90:1947-1956.

Brügemann, K., E. Gernand, U. König von Borstel, and S. König. 2012. Defining and evaluating heat stress thresholds in different dairy cow production systems. Arch. Tierzucht 55:13-24.

Brügemann, K., E. Gernand, U. U. von Borstel, and S. König. 2011. Genetic analyses of protein yield in dairy cows applying random regression models with time-dependent and temperature $\mathrm{x}$ humidity-dependent covariates. J. Dairy Sci. 94:4129-4139.

Calus, M. P. L., P. Bijma, and R. F. Veerkamp. 2004. Effects of data structure on the estimation of covariance functions to describe genotype by environment interactions in a reaction norm model. Genet. Sel. Evol. 36:489-507.

Calus, M. P. L., A. F. Groen, and G. de Jong. 2002. Genotype $\times$ Environment interaction for protein yield in Dutch dairy cattle as quantified by different models. J. Dairy Sci. 85:3115-3123.

Carabaño, M. J., K. Bachagha, M. Ramón, and C. Díaz. 2014. Modeling heat stress effect on Holstein cows under hot and dry conditions: Selection tools. J. Dairy Sci. 97:7889-7904.

Collier, R. J., G. E. Dahl, and M. J. VanBaale. 2006. Major advances associated with environmental effects on dairy cattle. J. Dairy Sci. 89:1244-1253.

Freitas, M. S., I. Misztal, J. Bohmanova, and J. West. 2006. Utility of on- and off-farm weather records for studies in genetics of heat tolerance. Livest. Sci. 105:223-228.

Gorniak, T., U. Meyer, K. H. Südekum, and S. Dänicke. 2014. Impact of mild heat stress on dry matter intake, milk yield and milk composition in mid-lactation Holstein dairy cows in a temperate climate. Arch. Anim. Nutr. 68:358-369.

Hammami, H., J. Bormann, N. M'hamdi, H. H. Montaldo, and N. Gengler. 2013. Evaluation of heat stress effects on production traits and somatic cell score of Holsteins in a temperate environment. J. Dairy Sci. 96:1844-1855.

Hill, D. L., and E. Wall. 2015. Dairy cattle in a temperate climate: The effects of weather on milk yield and composition depend on management. Animal 9:138-149. 
Kadzere, C. T., M. R. Murphy, N. Silanikove, and E. Maltz. 2002. Heat stress in lactating dairy cows: A review. Livest. Prod. Sci. 77:59-91.

Kass, R. E. 1993. Bayes factors in practice. Statistician 42:551-560.

Lambertz, C., C. Sanker, and M. Gauly. 2014. Climatic effects on milk production traits and somatic cell score in lactating Holstein-Friesian cows in different housing systems. J. Dairy Sci. 97:319-329.

López-Romero, P., R. Rekaya, and M. J. Carabaño. 2003. Assessment of homogeneity vs. heterogeneity of residual variance in random regression test-day models in a Bayesian analysis. J. Dairy Sci. 86:3374-3385.

Misztal, I. 1999. Model to study genetic component of heat stress in dairy cattle using national data. J. Dairy Sci. 82(Suppl. 1):32. (Abstr.)

Misztal, I., S. Tsuruta, T. Strabel, B. Auvray, T. Druet, and D. H. Lee. 2002. BLUPF90 and related programs. Proc. 7th World Congress in Genetics Applied to Livestock Production, August 19-23, 2002, Montpellier, France. Communication No. 28-07.

Muggeo, V. M. R. 2003. Estimating regression models with unknown break-points. Stat. Med. 22:3055-3071.

Muggeo, V. M. R. 2008. Segmented: an R package to fit regression models with broken-line relationships. $\mathrm{R}$ News 8/1, 20-25. http:// cran.r-project.org/doc/Rnews/.

NRC. 1971. A Guide to Environmental Research on Animals. Natl Acad. Sci., Washington, DC.

Peel, M. C., B. L. Finlayson, and T. A. McMahon. 2007. Updated world map of the Köppen-Geiger climate classification. Hydrol. Earth Syst. Sci. 11:1633-1644.

R Core Team. 2014. R: A language and environment for statistical computing, reference index version 3.1.1. R Foundation for Statistical Computing, Vienna, Austria. http://www.R-project.org/.

Ravagnolo, O., I. Misztal, and G. Hoogenboom. 2000. Genetic component of heat stress in dairy cattle, development of heat index function. J. Dairy Sci. 83:2120-2125.
Sánchez, J. P., I. Misztal, I. Aguilar, B. Zumbach, and R. Rekaya 2009. Genetic determination of the onset of heat stress on daily milk production in the US Holstein cattle. J. Dairy Sci. 92:40354045 .

Segnalini, M., U. Bernabucci, A. Vitali, A. Nardone, and N. Lacetera. 2013. Temperature humidity index scenarios in the Mediterranean basin. Int. J. Biometeorol. 57:451-458.

Smith, B. J. 2007. boa: An R package for MCMC output convergence assessment and posterior inference. J. Stat. Softw. 21:1-37.

Smith, D. L., T. Smith, B. J. Rude, and S. H. Ward. 2013. Short communication: Comparison of the effects of heat stress on milk and component yields and somatic cell score in Holstein and Jersey cows. J. Dairy Sci. 96:3028-3033.

St-Pierre, N. R., B. Cobanov, and G. Schnitkey. 2003. Economic losses from heat stress by US livestock industries. J. Dairy Sci. 86(E Suppl.):52-77.

West, J. W., B. G. Mullinix, and J. K. Bernard. 2003. Effects of hot humid weather on milk temperature, dry matter intake, and milk yield of lactating dairy cows. J. Dairy Sci. 86:232-242.

Yano, M., H. Shimadzu, and T. Endo. 2014. Modelling temperature effects on milk production: A study on Holstein cows at a Japanese farm. SpringerPlus 3:129.

Zimbelman, R. B., R. P. Rhoads, M. L. Rhoads, G. C. Duff, L. H. Baumgard, and R. J. Collier. 2009. A reevaluation of the impact of temperature humidity index (THI) and black globe humidity index (BGHI) on milk production in high producing dairy cows. Pages 158-168 in Proc. Southwest Nutrition and Management Conference, Tempe, AZ. R. J. Collier, ed. The University of Arizona, Tucson. 